\title{
Modeling exchange rate -interest rate differential nexus in BRICS: The role asymmetry and structural breaks
}

\author{
Zainab Sani $^{1}$ • Afees Salisu, ${ }^{2,3, *} \cdot$ Eucharia Onyia $^{1} \bullet$ Onyebuchi Anih $^{1} \bullet$ Lawrence Kanu$^{1}$ \\ ${ }^{1}$ Research Department, Central Bank of Nigeria, Nigeria \\ ${ }^{2}$ Department for Management of Science and Technology Development, Ton Duc Thang University, Vietnam \\ ${ }^{3}$ Faculty of Business Administration, Ton Duc Thang University, Vietnam
}

Received: 27 July 2019

Revised: 10 November 2019

Accepted: 15 November 2019

\begin{abstract}
This paper produces three new results for the interest rate differential - exchange rate nexus using data for the BRICS countries. One, it mostly validates the sticky price thesis which specifies negative relationship between interest rate differential and exchange rate in the countries. Two, further probe reveals that exchange rate predominantly responds asymmetrically to interest rate differential in four of the five countries. Three, the study reveals noteworthy result for China, showing that the nonlinearity in the nexus could be better captured with a threshold, rather than an asymmetric model.
\end{abstract}

Keywords: interest rate differential; asymmetry; structural breaks; BRICS

JEL Classification Codes: E43, F21, F31

\section{Introduction}

This study investigates the implications of interest rate differential for predicting exchange rate movements in BRICS countries. Previous evidences in support of the linkage are undeniable (see for example, Beng and Ying, 2010; Jackman et al., 2013; Moosa and Burns, 2014; Hacker et al., 2014; Ding and Yang, 2017; Galstyan and Velic, 2017). The theoretical motivation for the study is wrapped around the interest rate parity theory which accord significant role for nonzero interest rate differential to drive investment between the home and foreign economies and thereby serve as a predictor for exchange rate (see Auten, 1963, Hooper and Morton, 1982). ${ }^{1}$ Further motivation for the research derives from its investment undertone particularly for emerging BRICS economies whose growth pursuits require stability in the goods and financial markets (see Wulandari, 2012; Beju and Ciupac-Ulici, 2015).

\footnotetext{
* Corresponding author. E-mail: afees.adebare.salisu@tdtu.edu.vn.
}

Citation: Sani, Z., Salisu, A., Onyia, E., Anih, O., and Kanu, L. (2020) Modeling exchange rate-interest rate differential nexus in BRICS: The role asymmetry and structural breaks, Economics and Business Letters, 9(2), 73-83.

DOI: 10.17811/ebl.9.2.2020.73-83

\footnotetext{
${ }^{1}$ The more explicit theoretical models that define the nature of the relationship although differently are the stickyprice approach which specifies the (short run) relationship as negative and the flexible-price approach which outlines positive relationship.
} 
The major contribution of this study is the consideration of asymmetry in the relationship in addition to its being a cross-country analysis. The theory emphasises nonlinearity in the relationship when it envisages different effects of positive and negative interest rate differential on exchange rate. The theory suggests a positive relationship (which leads to exchange rate appreciation) when interest rate differential favours the foreign country, and the reverse when it favours the home economy (see Auten, 1963). Several empirical evidences in our support indicate that exchange rates are better predicted within a nonlinear modelling framework (see Meese and Rogoff, 1983; Kilian and Taylor, 2003; Vygodina et al., 2008). Hence, we expect dissimilar response (i.e. asymmetric effects) of exchange rate to positive and negative interest rate differentials as well as possible differences in short and long run estimates (see Engel, 2016). We capture these asymmetric effects with a nonlinear autoregressive distributed lag (ARDL) technique ${ }^{2}$ and return with interesting findings.

Following the introduction is the methodology section. Section 3 introduces the data and preliminary results. Section 4 discusses the main findings and Section 5 concludes the paper.

\section{Methodology}

The flexible/sticky-price monetary models (Hooper and Morton, 1982; Bilson, 1978; Frenkel, 1976; Dornbusch, 1976) in line with the assumption of interest rate parity are adequate for explaining the interest rate differential and exchange rate nexus. The synthesis of the models identifies the predictors of bilateral exchange rate to include relative differences in: short-term interest rate, prices, money growth, and output growth between the home country (each of the BRICS countries) and the foreign country (the US as the reference economy). This relation is true when the uncovered interest and purchasing power parities hold between the two economies (see Frankel, 1979).

We reduce this theoretical construction into an Autoregressive Distributed Lag (ARDL) model:

$$
\begin{gathered}
\Delta e_{t}=c+\phi_{1} e_{t-1}+\beta_{1}\left(\pi_{t-1}-\pi_{t-1}^{*}\right)+\delta_{1}\left(m s_{t-1}-m s_{t-1}^{*}\right)+\lambda_{1}\left(i_{t-1}-i_{t-1}^{*}\right)+ \\
\gamma_{1}\left(y_{t-1}-y_{t-1}^{*}\right)+\sum_{j=1}^{p} \phi_{2 j} \Delta e_{t-j}+\sum_{i=0}^{q_{1}} \beta_{2 i} \Delta\left(\pi_{t-i}-\pi_{t-i}^{*}\right)+\sum_{i=0}^{q_{2}} \delta_{2 i} \Delta\left(m s_{t-i}-\right. \\
\left.m s_{t-i}^{*}\right)+\sum_{i=0}^{q_{3}} \lambda_{2 i} \Delta\left(i_{t-i}-i_{t-i}^{*}\right)+\sum_{i=0}^{q_{4}} \gamma_{2 i} \Delta\left(y_{t-i}-y_{t-i}^{*}\right)+\varepsilon_{t}
\end{gathered}
$$

where $e_{t}$ is the logarithm (log) of the bilateral exchange rate to the US\$ (domestic currency/\$); $\pi_{t}$ is the inflation rate, $m s_{t}$ is the log of the domestic nominal money supply, $i_{t}$ is the interest rate, $y_{t}$ is the log of domestic output, the variables denoted with asterisk are corresponding foreign variables (using US data), $c$ is an arbitrary constant, and $\varepsilon_{t}$ is a disturbance term.

Given the focus of the study to tease out the nonlinear asymmetric response of exchange rate to interest rate differential, we specify the nonlinear ARDL variant that captures asymmetry in Eq. (2).

$$
\begin{gathered}
\Delta e_{t}=c+\phi_{1} e_{t-1}+\beta_{1}\left(\pi_{t-1}-\pi_{t-1}^{*}\right)+\delta_{1}\left(m_{t-1}-m_{t-1}^{*}\right)+\lambda_{1}^{+}\left(i_{t-1}-i_{t-1}^{*}\right)^{+}+ \\
\lambda_{1}^{-}\left(i_{t-1}-i_{t-1}^{*}\right)^{-}+\gamma_{1}\left(y_{t-1}-y_{t-1}^{*}\right)+\sum_{j=1}^{p} \phi_{2 j} \Delta e_{t-j}+\sum_{i=0}^{q_{1}} \beta_{2 i} \Delta\left(\pi_{t-i}-\pi_{t-i}^{*}\right)+ \\
\sum_{i=0}^{q_{2}} \delta_{2 i} \Delta\left(m_{t-i}-m_{t-i}^{*}\right)+\sum_{i=0}^{q_{3}} \lambda_{2 i}^{+} \Delta\left(i_{t-i}-i_{t-i}^{*}\right)^{+}+\sum_{i=0}^{q_{4}} \lambda_{2 i}^{-} \Delta\left(i_{t-i}-i_{t-i}^{*}\right)^{-}+ \\
\sum_{i=0}^{q_{5}} \gamma_{2 i} \Delta\left(y_{t-i}-y_{t-i}^{*}\right)+\varepsilon_{t}
\end{gathered}
$$

We follow the technique of Shin et al. (2014) in decomposing interest rate differential into positive and negative partial sums as $\left(i_{t-1}-i_{t-1}^{*}\right)^{+}$and $\left(i_{t-1}-i_{t-1}^{*}\right)^{-}$:

\footnotetext{
${ }^{2}$ Some of the remarkable features of the technique can be found in Fauzel (2017) and Woo and Lee (2018).

${ }^{3}$ The attractions for choosing ARDL model is consistent with the earlier stated objective of obtaining short run and long run estimates and the mixed order of integration of the underlying series.
} 


$$
\begin{aligned}
& \left(i_{t-1}-i_{t-1}^{*}\right)^{+}=\sum_{k=1}^{t} \Delta\left(i_{t-1}-i_{t-1}^{*}\right)^{+}=\sum_{k=1}^{t} \max \left(\Delta\left(i_{t-1}-i_{t-1}^{*}\right), 0\right) \\
& \left(i_{t-1}-i_{t-1}^{*}\right)^{-}=\sum_{k=1}^{t} \Delta\left(i_{t-1}-i_{t-1}^{*}\right)^{-}=\sum_{k=1}^{t} \min \left(\Delta\left(i_{t-1}-i_{t-1}^{*}\right), 0\right)
\end{aligned}
$$

Figure 1. Exchange rate, interest rate and interest rate differentials in the BRICS countries.

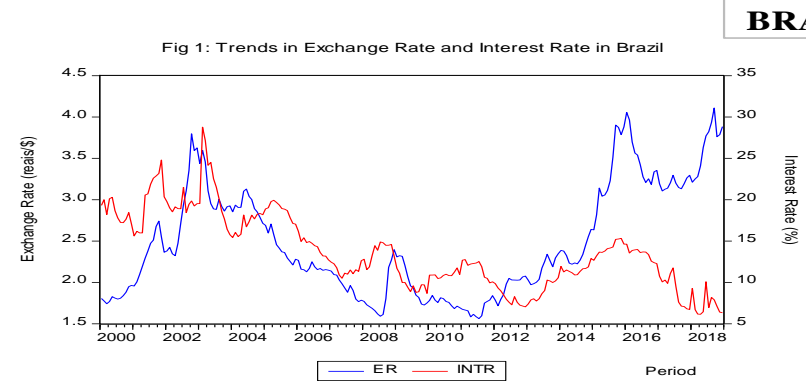

BRAZIL
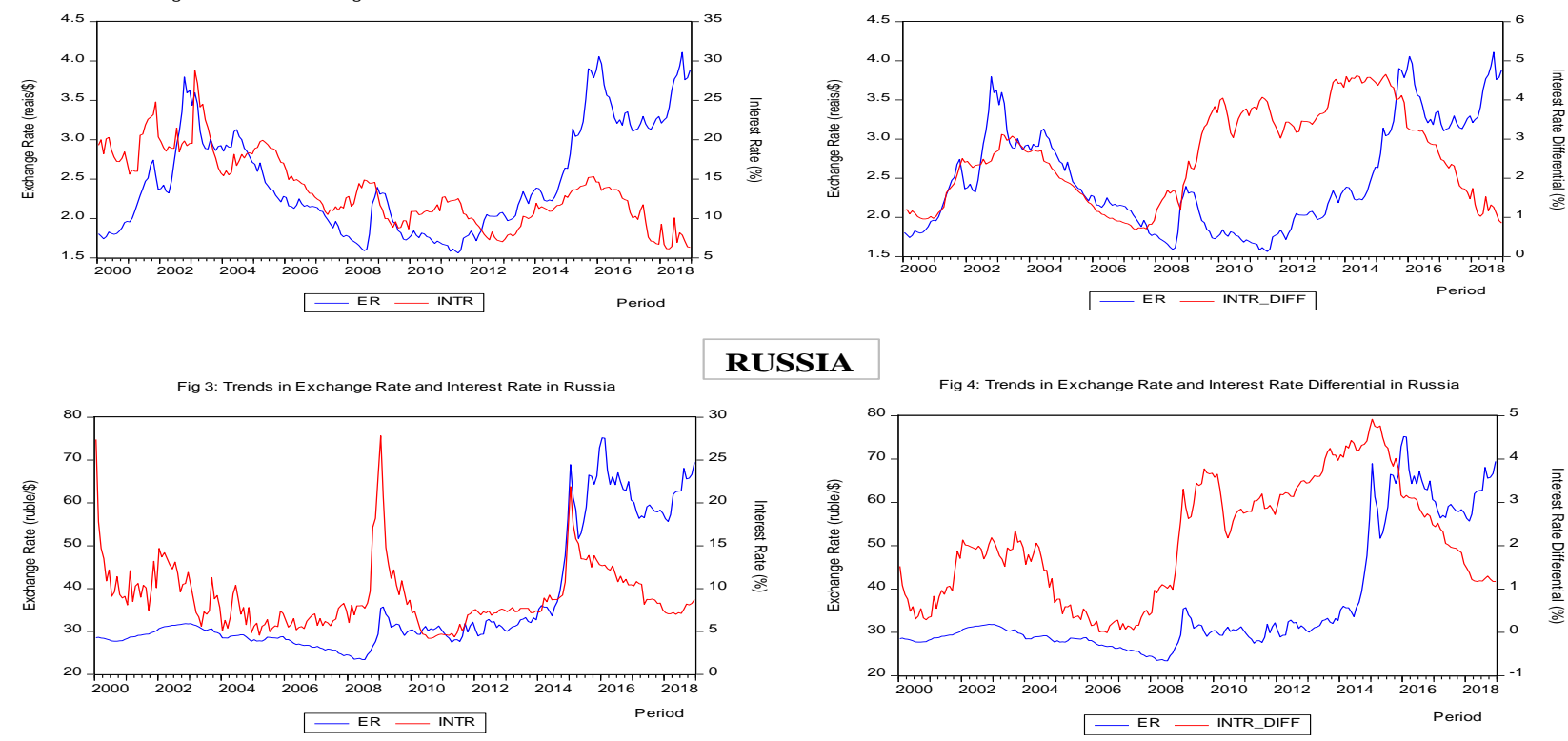

RUSSIA

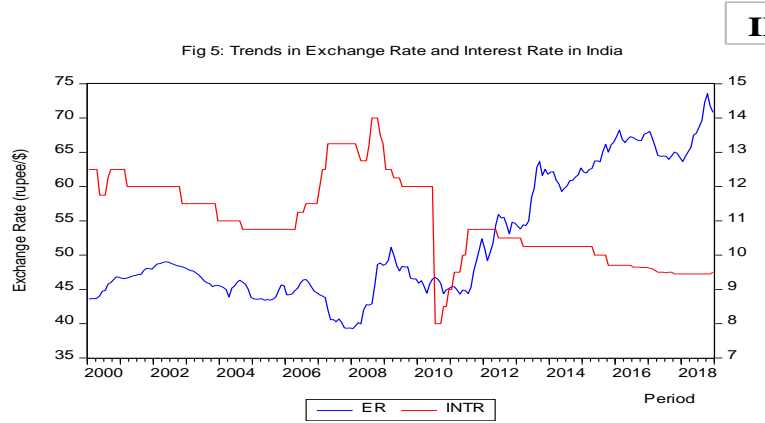

INDIA

Fig 6: Trends in Exchange Rate and Interest Rate Differential in India

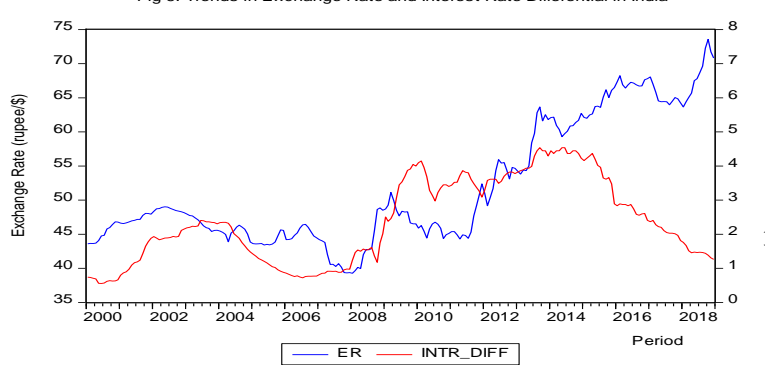

\section{CHINA}
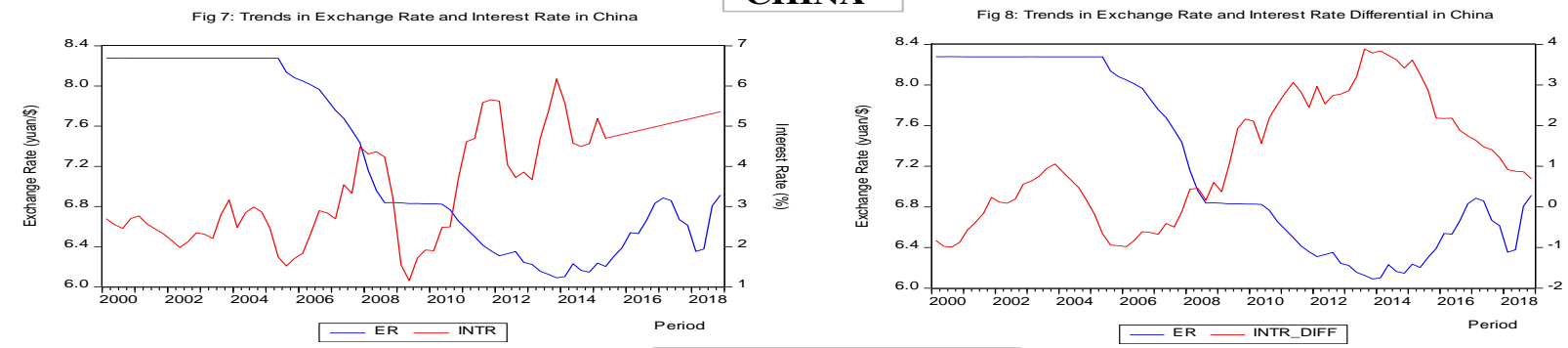

SOUTH AFRICA
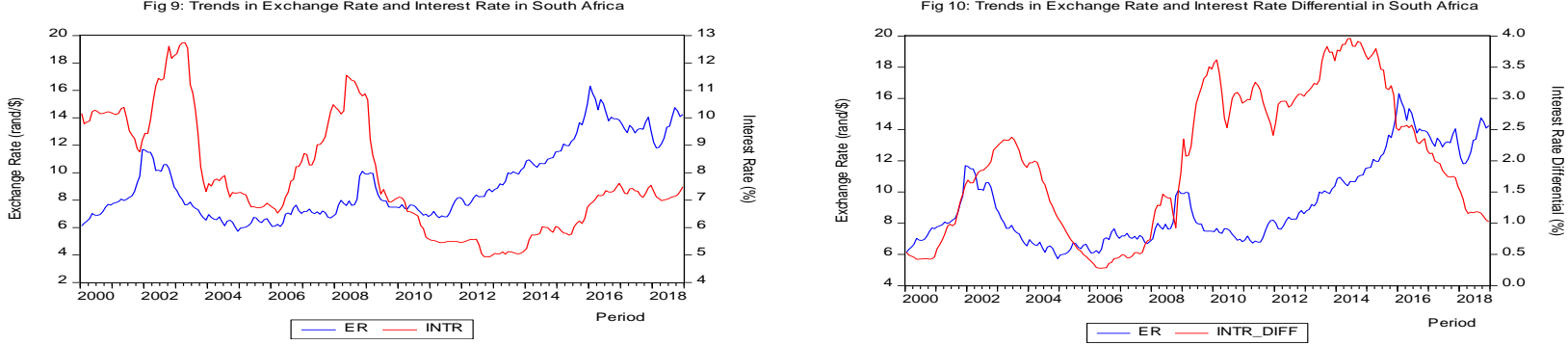
Table 1. Summary Statistics.

\begin{tabular}{|c|c|c|c|c|c|c|c|c|c|}
\hline BRAZIL & Mean & Std. Dev. & Skewness & Kurtosis & RUSSIA & Mean & Std. Dev. & Skewness & Kurtosis \\
\hline NER & 2.480 & 0.667 & 0.608 & 2.253 & NER & 36.728 & 13.932 & 1.359 & 3.238 \\
\hline INF & 0.511 & 0.382 & 2.176 & 12.464 & INF & 0.008 & 0.006 & 1.359 & 5.598 \\
\hline INTR & 13.384 & 4.739 & 0.306 & 3.316 & INTR & 8.901 & 3.522 & 1.739 & 7.817 \\
\hline IPIG & 0.079 & 6.496 & 0.032 & 2.941 & IPIG & 0.310 & 6.879 & -1.715 & 7.800 \\
\hline MS & 56.337 & 38.838 & 0.514 & 1.894 & MS & 49.278 & 40.757 & 0.524 & 1.891 \\
\hline CHINA & Mean & Std. Dev. & Skewness & Kurtosis & INDIA & Mean & Std. Dev. & Skewness & Kurtosis \\
\hline NER & 7.201 & 0.839 & 0.229 & 1.374 & NER & 51.866 & 9.045 & 0.707 & 2.050 \\
\hline INF & 0.537 & 1.048 & 0.301 & 2.918 & INF & 0.515 & 0.762 & 0.690 & 6.407 \\
\hline INTR & 3.600 & 1.343 & 0.053 & 1.623 & INTR & 11.006 & 1.246 & 0.175 & 2.453 \\
\hline IPIG & -0.065 & 1.515 & -0.068 & 6.188 & IPIG & 0.428 & 5.475 & -0.399 & 3.642 \\
\hline MS & 54.955 & 40.189 & 0.599 & 2.006 & MS & 55.363 & 38.326 & 0.522 & 1.911 \\
\hline S. AFRICA & Mean & Std. Dev. & Skewness & Kurtosis & Reference & Mean & Std. Dev. & Skewness & Kurtosis \\
\hline NER & 9.182 & 2.654 & 0.827 & 2.468 & US_INF & 0.175 & 0.382 & -0.882 & 6.817 \\
\hline INF & 0.432 & 0.440 & 0.297 & 3.831 & US_INTR & 1.953 & 1.962 & 0.987 & 2.691 \\
\hline INTR & 7.730 & 2.028 & 0.683 & 2.516 & US_IPIG & 0.070 & 1.810 & 0.034 & 3.381 \\
\hline IPIG & 99.877 & 2.414 & -1.632 & 13.486 & US_MS & 73.274 & 23.879 & 0.396 & 1.903 \\
\hline MS & 64.551 & 32.635 & 0.086 & 1.760 & & & & & \\
\hline
\end{tabular}

Note: $\mathrm{ER}=$ Bilateral Exchange Rate; IPIG = Growth in Industrial Production Index; INTR = Inter-bank Interest Rate; INF = Inflation; MS = Money Supply.

\section{Data and preliminary analysis}

\subsection{Data sources and description}

The study sourced the required dataset for BRICS countries from the International Monetary Fund's International Financial Statistics and the Federal Reserve Bank Database. The data cover 2000M01 to 2018M12 for the countries except China only available at quarterly frequency. The data are presented in turn. NER: Nominal exchange rate which is the bilateral exchange rate of the domestic currency against the US Dollar; INF: Inflation rate computed as $100 * \log ($ cpi/cpi(-1)); INT: Interest rate which is the domestic lending rate; IPIG: Industrial Production index Growth derived from the computation of the IPI growth rate as $100 * \log (\mathrm{IPI} / \mathrm{IPI}(-1))$; and MS: Money supply.

\subsection{Preliminary Analyses}

Following standard approach to time series modelling, we explore the statistical properties of the variables with descriptive statistics, graphical presentations and unit root tests. From Table 1 , using the mean values, India and Russia record the most exchange rate depreciation while Brazil and China experienced it the least during the review period. Brazil with the least exchange rate depreciation, the least volatile exchange rate series (judging by the standard deviation figures) also record the highest interest rate differential. On the other hand, India and Russia with the highest exchange rate depreciation have the most volatile exchange rates and the lowest interest rate differentials. To complement the summary statistics, the co-movements between the series are reported in Figure 1. The figures show that there are negligible differences between the graphs of exchange rate and interest rate and those of exchange rate and interest rate differential.

Further time series analyses based on the Augmented Dickey Fuller (ADF) unit root tests (with and without structural breaks) as employed in Table 2 indicate evidence of mixed order of integration and therefore lend support to our choice of ARDL estimation technique. The preliminary results also show that the presence of structural breaks is real in the data and should be reflected in the main analysis. We also test for the presence of co-integration using the Bounds test approach (see Table 3). The test was conducted on four variants of the ARDL 
models; linear ARDL, linear ARDL with structural breaks, nonlinear ARDL, and nonlinear ARDL with structural breaks. We are able to reject the null of no co-integration with the linear model in Brazil, linear model with structural breaks in the case of Russia, India and South Africa. The exception is China where we find no evidence of co-integration irrespective of the variant of ARDL model considered.

Table 2. Unit Root Test Results.

\begin{tabular}{|c|c|c|c|c|c|c|}
\hline \multicolumn{7}{|c|}{ BRAZIL } \\
\hline$V A R I A B L E$ & WOSB & $I(d)$ & $V A R I A B L E$ & $W S B$ & $I(d)$ & BREAK DATE \\
\hline $\log (\mathrm{cpi})$ & $-7.112638[0]^{\mathrm{a}, \#}$ & $\mathrm{I}(1)$ & $\log (\mathrm{cpi})$ & $-8.836730[0]^{\mathrm{a}, \wedge}$ & $\mathrm{I}(1)$ & 2002M11 \\
\hline $\log (e r)$ & $-9.914049[1]^{\mathrm{a} \wedge}$ & $\mathrm{I}(1)$ & $\log (\mathrm{er})$ & $-10.95940[0]^{\mathrm{a}, \#}$ & $\mathrm{I}(1)$ & 2002M10 \\
\hline $\log (\mathbf{i p i})$ & $-4.522002[15]^{\mathrm{a}, \#}$ & $\mathrm{I}(1)$ & $\log ($ ipi $)$ & $-18.69667[0]^{\mathrm{a}, \wedge}$ & $\mathrm{I}(1)$ & 2000M12 \\
\hline $\log (\mathbf{m s})$ & $-4.216928[4]^{\mathrm{a}, \#}$ & $\mathrm{I}(1)$ & $\log (\mathrm{ms})$ & $-8.273656[0]^{\mathrm{a}, \#}$ & $\mathrm{I}(1)$ & 2000M6 \\
\hline $\log ($ intr $)$ & $-17.65643[0]^{\mathrm{a}, \wedge}$ & $\mathrm{I}(1)$ & $\log$ (intr) & $-19,36568[0]^{\mathrm{a}^{\wedge}}$ & $\mathrm{I}(1)$ & 2018M06 \\
\hline \multicolumn{7}{|c|}{ RUSSIA } \\
\hline$V A R I A B L E$ & WOSB & $I(d)$ & $V A R I A B L E$ & $W S B$ & $I(d)$ & BREAK DATE \\
\hline $\log (\mathbf{c p i})$ & $-3.900243[12]^{a, \#}$ & $\mathrm{I}(1)$ & $\log (\mathrm{cpi})$ & $-7.974782[0]^{\mathrm{a}, \#}$ & $\mathrm{I}(1)$ & 2001M06 \\
\hline $\log (\mathrm{er})$ & $-11.35222[0]^{\mathrm{a}, \#}$ & $\mathrm{I}(1)$ & $\log (\mathrm{er})$ & $-12,81438[0]^{\mathrm{a}, \#}$ & $\mathrm{I}(1)$ & 2015M01 \\
\hline $\log (\mathbf{i p i})$ & $-3.821090[11]^{\mathrm{a}, \#}$ & $\mathrm{I}(1)$ & $\log ($ ipi $)$ & $-19.75439[0]^{\mathrm{a}, \wedge}$ & $\mathrm{I}(1)$ & 2000M05 \\
\hline $\log (\mathrm{ms})$ & $-4.949349[4]^{\mathrm{a}, \#}$ & $\mathrm{I}(1)$ & $\log (\mathrm{ms})$ & $-7.782428[0]^{\mathrm{a}, \#}$ & $\mathrm{I}(1)$ & 2000M01 \\
\hline $\log ($ intr $)$ & $-8.783821[3]^{\mathrm{a}, \wedge}$ & $\mathrm{I}(1)$ & $\log$ (intr) & $-18.24219[0]^{\mathrm{a}, \wedge}$ & $\mathrm{I}(1)$ & 2004M01 \\
\hline \multicolumn{7}{|c|}{ INDIA } \\
\hline$V A R I A B L E$ & $W O S B$ & $I(d)$ & $V A R I A B L E$ & $W S B$ & $I(d)$ & $B R E A K D A T E$ \\
\hline $\log (\mathbf{c p i})$ & $-12.619[10]^{\mathrm{a}}$ & $\mathrm{I}(2)$ & $\log (\mathrm{cpi})$ & $-11.731[0] \mathrm{a}, \wedge$ & $\mathrm{I}(1)$ & $2000 \mathrm{M} 12$ \\
\hline $\log (\mathrm{er})$ & $-10.512[0]^{\mathrm{a}, \wedge}$ & $\mathrm{I}(1)$ & $\log (\mathrm{er})$ & $-11.072[0] \mathrm{a}, \wedge$ & $\mathrm{I}(1)$ & 2008M10 \\
\hline og(ipi) & $-3.466[12]^{\mathrm{b}, \#}$ & $\mathrm{I}(1)$ & $\log ($ ipi $)$ & $-29.323[0] \mathrm{a}, \wedge$ & $\mathrm{I}(1)$ & 2000M12 \\
\hline $\log (\mathrm{ms})$ & $-3.340[6]^{\mathrm{c}, \#}$ & $\mathrm{I}(1)$ & $\log (\mathrm{ms})$ & $-29.323[0] \mathrm{a}, \#$ & $\mathrm{I}(1)$ & $2000 \mathrm{~m} 08$ \\
\hline $\log ($ intr $)$ & $-14.532[0]^{\mathrm{a}}$ & $\mathrm{I}(1)$ & $\log$ (intr) & $-14.897[0] \mathrm{a}, \#$ & $\mathrm{I}(1)$ & 2010M10 \\
\hline \multicolumn{7}{|c|}{ CHINA } \\
\hline$V A R I A B L E$ & WOSB & $I(d)$ & $V A R I A B L E$ & $W S B$ & $I(d)$ & BREAK DATE \\
\hline $\log (\mathbf{c p i})$ & $-4.862[5]^{\mathrm{a}, \wedge}$ & $\mathrm{I}(1)$ & $\log (\mathrm{cpi})$ & $-8.393[0]^{\mathrm{a}, \#}$ & $\mathrm{I}(1)$ & $2003 \mathrm{Q} 3$ \\
\hline $\log (e r)$ & $-5.405[0]^{\mathrm{a}, \#}$ & $\mathrm{I}(1)$ & $\log (\mathrm{er})$ & $-6.869[0]^{\mathrm{a}, \#}$ & $\mathrm{I}(1)$ & 2018 Q1 \\
\hline $\log (\mathbf{i p i})$ & $-6.081[3]^{\mathrm{a}, \#}$ & $\mathrm{I}(1)$ & $\log ($ ipi $)$ & $-10.548[0]^{\mathrm{a}, \wedge}$ & $\mathrm{I}(1)$ & 2009 Q4 \\
\hline $\log (\mathrm{ms})$ & $-4.982[0]^{\mathrm{a}, \#}$ & $\mathrm{I}(1)$ & $\log (\mathrm{ms})$ & $-5.761[0]^{\mathrm{a}, \#}$ & $\mathrm{I}(1)$ & 2009 Q1 \\
\hline $\log ($ intr $)$ & $-3.884[1]^{\mathrm{a}, \#}$ & $\mathrm{I}(0)$ & $\log$ (intr) & $-8.074[0]^{\mathrm{a}, \wedge}$ & $\mathrm{I}(1)$ & 2009 Q1 \\
\hline \multicolumn{7}{|c|}{ SOUTH AFRICA } \\
\hline VARIABLE & WOSB & $I(d)$ & $V A R I A B L E$ & $W S B$ & $I(d)$ & BREAK DATE \\
\hline $\log (\mathbf{c p i})$ & $-9.768[0] \mathrm{a}, \wedge$ & $\mathrm{I}(1)$ & $\log (\mathrm{cpi})$ & $-10.467[0] \mathrm{a}, \#$ & $\mathrm{I}(1)$ & $2002 \mathrm{M} 10$ \\
\hline $\log (\mathrm{er})$ & $-10.986[0] \mathrm{a}, \wedge$ & $\mathrm{I}(1)$ & $\log (e r)$ & -12.294 [0]a,\# & $\mathrm{I}(1)$ & $2001 \mathrm{M} 12$ \\
\hline $\log (\mathbf{i p i})$ & $-4.558[2] \mathrm{a}, \#$ & $\mathrm{I}(1)$ & $\log ($ ipi $)$ & $-13.004[0] \mathrm{a}, \wedge$ & $\mathrm{I}(1)$ & 2001M05 \\
\hline $\log (\mathrm{ms})$ & $-4.285[6] \mathrm{a}, \#$ & $\mathrm{I}(1)$ & $\log (\mathrm{ms})$ & $-7.640[0] \mathrm{a}, \wedge$ & $\mathrm{I}(1)$ & 2000M05 \\
\hline $\log ($ intr $)$ & $-8.918[0] a, \#$ & $\mathrm{I}(0)$ & $\log$ (intr) & $-9.642[0] \mathrm{a}, \wedge$ & $\mathrm{I}(1)$ & 2003M10 \\
\hline \multicolumn{7}{|c|}{ Reference Country (US) } \\
\hline $\log \left(u s \_c p i\right)$ & $-9.851845[1]^{\mathrm{a}, \#}$ & $\mathrm{I}(1)$ & $\log \left(\mathrm{us} \_\mathrm{cpi}\right)$ & $-10.99778[1]^{\mathrm{a}^{\wedge}}$ & $\mathrm{I}(1)$ & 2008M11 \\
\hline $\log \left(\mathbf{u s \_ i p i )}\right.$ & $-4.522002[15]^{\mathrm{a}, \#}$ & $\mathrm{I}(1)$ & log(us_ipi) & $-24.30762[0]^{\mathrm{a}, \wedge}$ & $\mathrm{I}(1)$ & 2000M06 \\
\hline $\log \left(\mathbf{u s} \_m s\right)$ & $-12.14529[0]^{\mathrm{a}, \#}$ & $\mathrm{I}(1)$ & log(us_ms) & $-13.32207[0]^{\mathrm{a}, \#}$ & $\mathrm{I}(1)$ & 2000M06 \\
\hline
\end{tabular}

Note: $\mathrm{a}, \mathrm{b}$ and c denote $1 \%, 5 \%$ and $10 \%$ level of statistical significance; WOSB = without structural breaks; WSB $=$ with structural breaks; ${ }^{\wedge}$ represents test with intercept; \# represents test with trend and intercept. 
Table 3. Summary of Cointegration test results.

\begin{tabular}{lrrr}
\hline Country & F-test Statistics & ARDL(p,q,q,q,q) & Remark \\
\hline Brazil & 5.38 & $(2,0,0,0,3)$ & Cointegration @ 5\% \\
Russia & 7.00 & $(2,0,1,0,4)$ & Cointegration @ $1 \%$ \\
India & 5.80 & $(2,1,0,0,0)$ & Cointegration @ 5\% \\
China & 2.08 & $(2,0,0,0,0,0)$ & No Cointegration @ $10 \%$ \\
South Africa & 3.80 & $(2,0,0,0,0)$ & Cointegration @ $10 \%$ \\
\hline \hline
\end{tabular}

Note. The null hypothesis of no Cointegration are evaluated for $1 \%, 5 \%$ and $10 \%$ significance levels as indicated in the remarks.

\section{Discussion of results}

In Table 4, we present the comprehensive results of the four variants of the ARDL models yielding the short and long-run estimates for the interest rate differential-exchange rate relationship for each of the BRICS countries. Starting with the linear ARDL model (with and without structural breaks) which assumes symmetric response of exchange rate to interest rate differential, we find that changes in exchange rate can be explained by the differential in interest rate in the short-run in India and South Africa and in the long run in Brazil. As expected of a country with a fixed exchange rate regime, we find no evidence of significant relationship between the China-US exchange rate and interest rate differential in both the short and longrun. The coefficients return with negative signs (supporting the sticky-price model) in most of the cases except in Russia.

Motivated by the argument that exchange rate could respond asymmetrically to interest rate differential, we further account for non-linearity in the ARDL framework. We address this in the two variants of linear ARDL models; the one without and the one with structural breaks. Results confirm our surmise that exchange rate movement indeed respond asymmetrically to interest rate differential in most of the economies (four out of the five BRICS countries). In Brazil, with and without structural breaks in the nonlinear model estimated, asymmetry matters in both short and the long run; in China, asymmetry is evident in both time horizons without accounting for structural breaks. However, accounting for asymmetry only matters in the short run response of exchange rate to interest differential in India and South Africa. In Russia however, bearing statistical insignificance, there is also dissimilar impacts of negative and positive changes of interest rate differential on exchange rate whether we consider specification with or without structural breaks.

As a step forward, we construct the graphs of dynamic multipliers from the asymmetric models with a view to tease out the contributions of each of the regressors to the variations in the regressand (exchange rate) and also show the asymmetry more clearly (Huettner and Sunder, 2011 provided the necessary guide). Since we are more concerned with the asymmetric effects of interest rate differential on exchange rate movements, we limit our discussion to the graphs in the first quadrants in Figure 2. These show the asymmetric response of exchange rate to interest rate differential in four countries (Brazil, Russia, China and South Africa). Importantly, the asymmetry shown in China may be better captured with a threshold model. This may explain the result of no Cointegration reported for China for all the ARDL variants considered.

In all, we establish that interest rate differential is a major determinant of exchange rate movements in the BRICS countries. Beyond that, we show that the nexus is not monotonic but reflect asymmetry and the effect of structural breaks in the data. 
Table 4. ARDL and NARDL regression results.

\begin{tabular}{|c|c|c|c|c|}
\hline BRAZIL & $\begin{array}{c}A R D L \_W O S B \\
(2,0,0,0,3)\end{array}$ & $\begin{array}{c}A R D L_{-} W S B \\
(2,0,0,1,0)\end{array}$ & $\begin{array}{c}\text { NARDL_WOSB } \\
(2,0,0,0,0,0)\end{array}$ & $\begin{array}{c}\text { NARDL_WSB } \\
(2,0,0,0,0,0)\end{array}$ \\
\hline \multicolumn{5}{|c|}{ Long-Run } \\
\hline INTR & $0.1245^{\mathrm{b}}(0.0626)$ & $-0.0066(0.1084)$ & - & - \\
\hline INTR $^{+}$ & - & - & $0.1129^{\mathrm{b}}(0.0562)$ & $0.0233^{\mathrm{a}}(0.0785)$ \\
\hline INTR $^{-}$ & - & - & $-0.1244(0.0925)$ & $-0.0982^{\mathrm{c}}(0.0562)$ \\
\hline Control Variables & YES & YES & YES & YES \\
\hline \multicolumn{5}{|c|}{ Short-Run } \\
\hline$\Delta \mathrm{INTR}$ & $-0.0227(0.0154)$ & $-0.0002(0.0031)$ & - & - \\
\hline$\Delta \mathrm{INTR}^{+}$ & - & - & $0.0063^{\mathrm{c}}(0.0043)$ & $0.0191^{\mathrm{a}}(0.0057)$ \\
\hline$\Delta \mathrm{INTR}^{-}$ & - & - & $-0.0070^{c}(0.0037)$ & $-0.0080^{\mathrm{b}}(0.0037)$ \\
\hline Control Variables & YES & YES & YES & YES \\
\hline ECT & $-0.0537^{\mathrm{a}}(0.0103)$ & $-0.0283^{\mathrm{a}}(0.0141)$ & $-0.0559^{\mathrm{a}}(0.0168)$ & $-0.0817^{\mathrm{a}}(0.0186)$ \\
\hline \multicolumn{5}{|c|}{ Residual Diagnostics } \\
\hline Q-Stat (10) & 12.051 & 13.183 & 10.642 & 9.977 \\
\hline $\mathrm{Q}^{2}$-Stat $(10)$ & $17.761^{\mathrm{b}}$ & $36.300^{\mathrm{a}}$ & $30.070^{\mathrm{a}}$ & $29.406^{\mathrm{a}}$ \\
\hline \multicolumn{5}{|c|}{ ARCH LM } \\
\hline ARCH LM (5) & 0.3764 & 0.3976 & 0.7042 & 0.3912 \\
\hline ARCH LM (10) & 1.3594 & 1.5323 & 1.1381 & 1.3251 \\
\hline \multicolumn{5}{|c|}{ Model Diagnostics } \\
\hline $\operatorname{Adj} R^{2}$ & 0.98 & 0.98 & 0.98 & 0.98 \\
\hline F-Statistic & $1292.83^{\mathrm{a}}$ & $1482.24^{\mathrm{a}}$ & $1717.67^{\mathrm{a}}$ & $1551.08^{\mathrm{a}}$ \\
\hline SIC & -3.7108 & -3.6587 & -3.6918 & -3.7033 \\
\hline AIC & -3.9778 & -3.7950 & -3.8129 & -3.8396 \\
\hline RUSSIA & $\begin{array}{c}\text { ARDL_WOSB } \\
(\mathbf{2}, \mathbf{0}, \mathbf{1}, \mathbf{0 , 4})\end{array}$ & $\begin{array}{c}\text { ARDL_WSB } \\
(\mathbf{2}, \mathbf{0 , 1}, \mathbf{0 , 4 )}\end{array}$ & $\begin{array}{c}\text { NARDL_WOSB } \\
(\mathbf{2}, 0,0,1,4,4)\end{array}$ & $\begin{array}{c}\text { NARDL_WSB } \\
(\mathbf{2 , 0 , 0 , 1 , 0 , 4 )}\end{array}$ \\
\hline \multicolumn{5}{|c|}{ Long-Run } \\
\hline INTR & $0.0084(0.0337)$ & $-0.0072(0.0172)$ & - & - \\
\hline INTR $^{+}$ & - & - & $-0.0232(0.0032)$ & $0.0511(0.0574)$ \\
\hline INTR $^{-}$ & - & - & $-0.0279(0.0327)$ & $-0.0033(0.0220)$ \\
\hline Control Variable & YES & YES & YES & YES \\
\hline \multicolumn{5}{|c|}{ Short-Run } \\
\hline$\triangle \mathrm{INTR}$ & $0.0006(0.0022)$ & $-0.0012(0.0027)$ & - & - \\
\hline$\Delta \mathrm{INTR}^{+}$ & - & - & $-0.0023(0.0031)$ & $0.0078(0.0081)$ \\
\hline$\Delta \mathrm{INTR}^{-}$ & - & - & $-0.00270(0.0032)$ & $-0.0005(0.0034)$ \\
\hline Control Variable & YES & YES & YES & YES \\
\hline ECT & $-0.0652^{\mathrm{a}}(0.0188)$ & $-0.1612^{\mathrm{a}}(0.0270)$ & $-0.0978^{\mathrm{a}}(0.0207)$ & $-0.1531^{\mathrm{a}}(0.0253)$ \\
\hline \multicolumn{5}{|c|}{ Residual Diagnostics } \\
\hline Q-Stat (10) & 14.051 & $16.501^{\mathrm{c}}$ & $16.007^{\mathrm{c}}$ & 15.376 \\
\hline $\mathrm{Q}^{2}$-Stat $(10)$ & $77.817^{\mathrm{a}}$ & $55.230^{\mathrm{a}}$ & $56.506^{\mathrm{a}}$ & $50.316^{\mathrm{a}}$ \\
\hline ARCH LM (5) & $2.6617^{\mathrm{b}}$ & 1.8311 & 1.1974 & 1.4011 \\
\hline ARCH LM (10) & 2.2159 & $2.0143^{\mathrm{b}}$ & $1.9861^{\mathrm{b}}$ & $1.8498^{c}$ \\
\hline \multicolumn{5}{|c|}{ Model Diagnostics } \\
\hline $\operatorname{Adj} R^{2}$ & 0.99 & 0.99 & 0.99 & 0.99 \\
\hline F-Statistics & $1591.68^{\mathrm{a}}$ & $1751.91^{\mathrm{a}}$ & $1485.09^{\mathrm{a}}$ & $1633.25^{\mathrm{a}}$ \\
\hline SIC & -3.9369 & -3.8377 & -3.7674 & -3.8171 \\
\hline AIC & -4.0352 & -4.0661 & -4.0264 & -4.0608 \\
\hline INDIA & $\begin{array}{c}\text { ARDL_WOSB } \\
(2,1,0,0,0)\end{array}$ & $\begin{array}{c}\text { ARDL_WSB } \\
(2,1,0,0,0)\end{array}$ & $\begin{array}{c}\text { NARDL_WOSB } \\
(2,1,0,0,0)\end{array}$ & $\begin{array}{c}\text { NARDL_WSB } \\
(2,1,0,0,0)\end{array}$ \\
\hline \multicolumn{5}{|c|}{ Long-Run } \\
\hline INTR & $-8.29 \mathrm{E}-05(0.0143)$ & $-0.0289^{c}(0.0165)$ & & \\
\hline $\mathrm{INTR}^{+}$ & & & $0.0059(0.0380)$ & $-0.0229 \quad(0.0376)$ \\
\hline INTR $^{-}$ & & & $-0.0100(0.0233)$ & $-0.0261(0.0220)$ \\
\hline Control Variable & YES & YES & YES & YES \\
\hline \multicolumn{5}{|c|}{ Short-Run } \\
\hline$\Delta \mathrm{INTR}$ & $-0.0206^{\mathrm{b}}(0.0084)$ & $-0.0024^{\mathrm{c}}(0.0013)$ & & \\
\hline$\Delta \operatorname{INTR}(-1)$ & $0.0205^{\mathrm{b}} \quad(0.0085)$ & & & \\
\hline$\Delta \mathrm{INTR}^{+}$ & & & $0.0005(0.0033)$ & $-0.0022(0.0035)$ \\
\hline$\Delta \mathrm{INTR}^{-}$ & & & $-0.03634^{\mathrm{b}}(0.0143)$ & \\
\hline Control Variable & YES & YES & YES & YES \\
\hline ECT & $-0.0779^{\mathrm{a}}(0.0174)$ & $-0.0826^{\mathrm{a}}(0.0152)$ & $-0.0865^{\mathrm{a}}(0.0177)$ & $-0.0939^{\mathrm{a}}(0.0171)$ \\
\hline & & Residual Diag & & \\
\hline Q-Stat (10) & 15.058 & 11.821 & 14.010 & 11.606 \\
\hline
\end{tabular}




\begin{tabular}{|c|c|c|c|c|}
\hline $\mathrm{Q}^{2}$-Stat (10) & $50.034^{\mathrm{a}}$ & 46.976 & $50.829^{\mathrm{a}}$ & 50.993 \\
\hline ARCH LM (5) & $6.1635^{\mathrm{a}}$ & $6.1254^{\mathrm{a}}$ & $6.4662^{\mathrm{a}}$ & $6.7972^{\mathrm{a}}$ \\
\hline ARCH LM (10) & $3.6114^{\mathrm{a}}$ & $4.2303^{\mathrm{a}}$ & $3.7053^{\mathrm{a}}$ & $4.3059^{\mathrm{a}}$ \\
\hline \multicolumn{5}{|c|}{ Model Diagnostics } \\
\hline R-squared & 0.992212 & 0.992536 & 0.992232 & 0.247759 \\
\hline $\begin{array}{l}\text { Adjusted R- } \\
\text { squared }\end{array}$ & 0.991962 & 0.992225 & 0.991945 & 0.230663 \\
\hline AIC & -5.528421 & -5.553187 & -5.522043 & -5.577399 \\
\hline SIC & -5.407340 & -5.401836 & -5.385827 & -5.486589 \\
\hline CHINA & $\begin{array}{c}\text { ARDL_WOSB } \\
(\mathbf{2 , 0 , 0 , 0 , 0 )}\end{array}$ & $\begin{array}{c}\text { ARDL_WSB } \\
(2,0,0,0,0)\end{array}$ & NARDL_WOSB & NARDL_WSB \\
\hline \multicolumn{5}{|c|}{ Long-Run } \\
\hline INTR & $-0.0275(0.026)$ & $-0.0345 \quad(0.019)$ & & \\
\hline $\mathrm{INTR}^{+}$ & & - & $0.0471(0.0380)$ & $0.0331(0.0308)$ \\
\hline INTR $^{-}$ & - & - & $-0.0915^{\mathrm{a}}(0.0329)$ & $-0.0497(0.0369)$ \\
\hline Control Variable & YES & YES & YES & YES \\
\hline \multicolumn{5}{|c|}{ Short-Run } \\
\hline$\triangle \mathrm{INTR}$ & $-0.0019(0.002)$ & $-0.003(0.002)$ & & \\
\hline$\Delta \mathrm{INTR}^{+}$ & & & $0.0058(0.0037)$ & $0.00478(0.0038)$ \\
\hline$\Delta \mathrm{INTR}^{-}$ & & & $-0.0112^{\mathrm{b}}(0.0042)$ & $-0.0072(0.0053)$ \\
\hline Control Variable & YES & YES & YES & YES \\
\hline ECT & $-0.068^{\mathrm{b}}(0.028)$ & $-0.096^{\mathrm{b}}(0.042)$ & $-0.1225 \mathrm{a}(0.0335)$ & $-0.1447^{\mathrm{b}}(0.0437)$ \\
\hline \multicolumn{5}{|c|}{ Residual Diagnostics } \\
\hline Q-Stat (10) & 9.491 & 9.022 & 10.325 & 11.101 \\
\hline$Q^{2}-$ Stat $(10)$ & 12.471 & 13.715 & $21.404^{\mathrm{b}}$ & $19.365^{\mathrm{b}}$ \\
\hline ARCH LM (5) & $17.505^{\mathrm{a}}$ & $28.041^{\mathrm{a}}$ & $35.0882^{\mathrm{a}}$ & $31.312^{\mathrm{a}}$ \\
\hline ARCH LM (10) & $7.962^{\mathrm{a}}$ & $12.529^{a}$ & $16.4860^{\mathrm{a}}$ & $14.015^{\mathrm{a}}$ \\
\hline \multicolumn{5}{|c|}{ Model Diagnostics } \\
\hline R-squared & 0.988482 & 0.989084 & 0.989527 & 0.989758 \\
\hline $\begin{array}{l}\text { Adjusted r- } \\
\text { squared }\end{array}$ & 0.987451 & 0.987926 & 0.988416 & 0.988497 \\
\hline AIC & -5.771689 & -5.798325 & -5.839696 & -5.834983 \\
\hline SIC & -5.553737 & -5.549237 & -5.590608 & -5.554758 \\
\hline $\begin{array}{l}\text { SOUTH } \\
\text { AFRICA }\end{array}$ & $\begin{array}{c}\text { ARDL_WOSB } \\
(\mathbf{2}, 0,0,0,1)\end{array}$ & $\begin{array}{c}\text { ARDL_WSB } \\
(\mathbf{2}, 0,0,0,1)\end{array}$ & $\begin{array}{c}\text { NARDL_WOSB } \\
(\mathbf{2 , 0 , 0 , 0 , 0 , 0 )}\end{array}$ & $\begin{array}{c}\text { NARDL_WSB } \\
(\mathbf{2}, \mathbf{0 , 0 , 0 , 0 , 0 , )}\end{array}$ \\
\hline \multicolumn{5}{|c|}{ Long-Run } \\
\hline INTR & $-0.7031 \quad(2.2860)$ & & & \\
\hline $\mathrm{INTR}^{+}$ & - & & $0.31504(0.3157)$ & $0.05852(0.1265)$ \\
\hline INTR $^{--}$ & - & & $-0.4975(0.4214)$ & $-0.1288 \quad(0.0990)$ \\
\hline Control Variable & YES & YES & YES & YES \\
\hline \multicolumn{5}{|c|}{ Short-Run } \\
\hline$\triangle \mathrm{INTR}$ & $-0.0053^{\mathrm{C}}(0.0028)$ & & & \\
\hline$\Delta \mathrm{INTR}^{+}$ & & & $0.0092(0.0063)$ & $0.0049 \quad(0.0107)$ \\
\hline$\Delta \mathrm{INTR}^{-}$ & & & $-0.0146^{\mathrm{b}(0.0057)}$ & $-0.0109 \quad(0.0072)$ \\
\hline Control Variable & YES & YES & YES & YES \\
\hline ECT & $-0.0075^{\mathrm{a}}(0.0025)$ & & $-0.029262^{\mathrm{a}}(0.0087)$ & $-0.0842^{\mathrm{a}}(0.0187)$ \\
\hline \multicolumn{5}{|c|}{ Serial Correlation } \\
\hline Q-Stat (10) & 11.455 & & 10.634 & 10.568 \\
\hline $\mathrm{Q}^{2}$-Stat (10) & 7.3472 & & 8.0781 & 5.9679 \\
\hline ARCH LM (5) & 0.0421 & & 0.0770 & 0.0807 \\
\hline ARCH LM (10) & 0.6508 & & & 0.5158 \\
\hline \multicolumn{5}{|c|}{ Model Diagnostics } \\
\hline R-Squared & 0.9829 & & 0.9827 & 0.9834 \\
\hline $\begin{array}{l}\text { Adjusted R- } \\
\text { squared }\end{array}$ & 0.9823 & & 0.9821 & 0.9827 \\
\hline AIC & -3.7706 & & -3.761250 & -3.7794 \\
\hline SIC & -3.649553 & & -3.6402 & -3.6129 \\
\hline
\end{tabular}

Note: $\mathrm{ARDL}=$ Autoregressive Distributed Lag Model; NARDL = Nonlinear ARDL; WOSB = Without Structural Break; WSB = With Structural Break; ECT = Error Correction Term; ARCH LM = Autoregressive Conditional Heteroscedasticity Lagrangian Multiplier test; AIC = Akaike Information Criterion; SIC = Schwartz Information Criterion; Q-Stat = Ljung-Box Residual Statistic; Q $^{2}$-Stat = Ljung-Box Squared Residual Statistic. 
Figure 2: The graphs of dynamic multipliers

\section{Brazil}
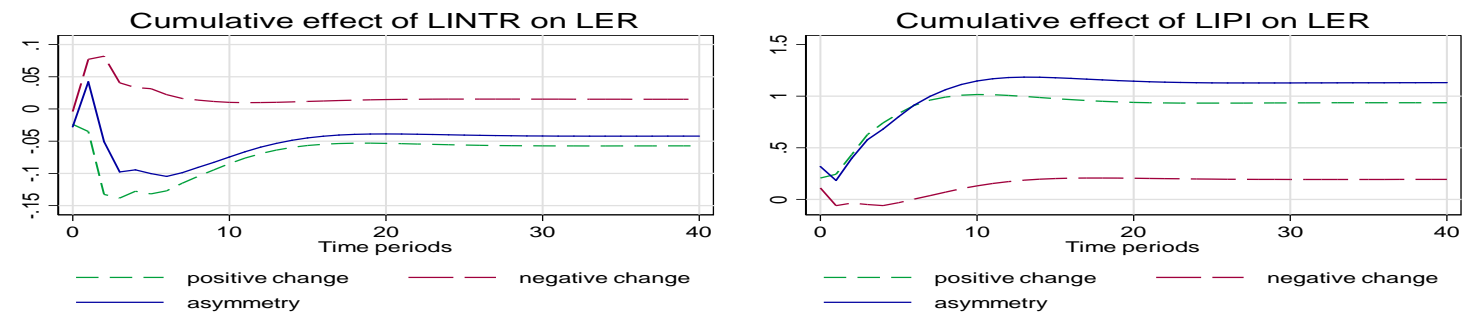

Cumulative effect of LCPI on LER
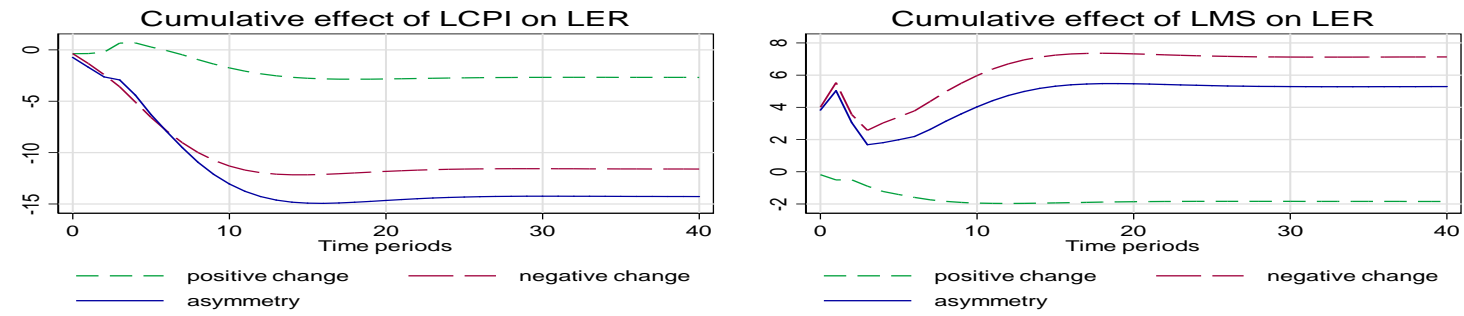

Russia
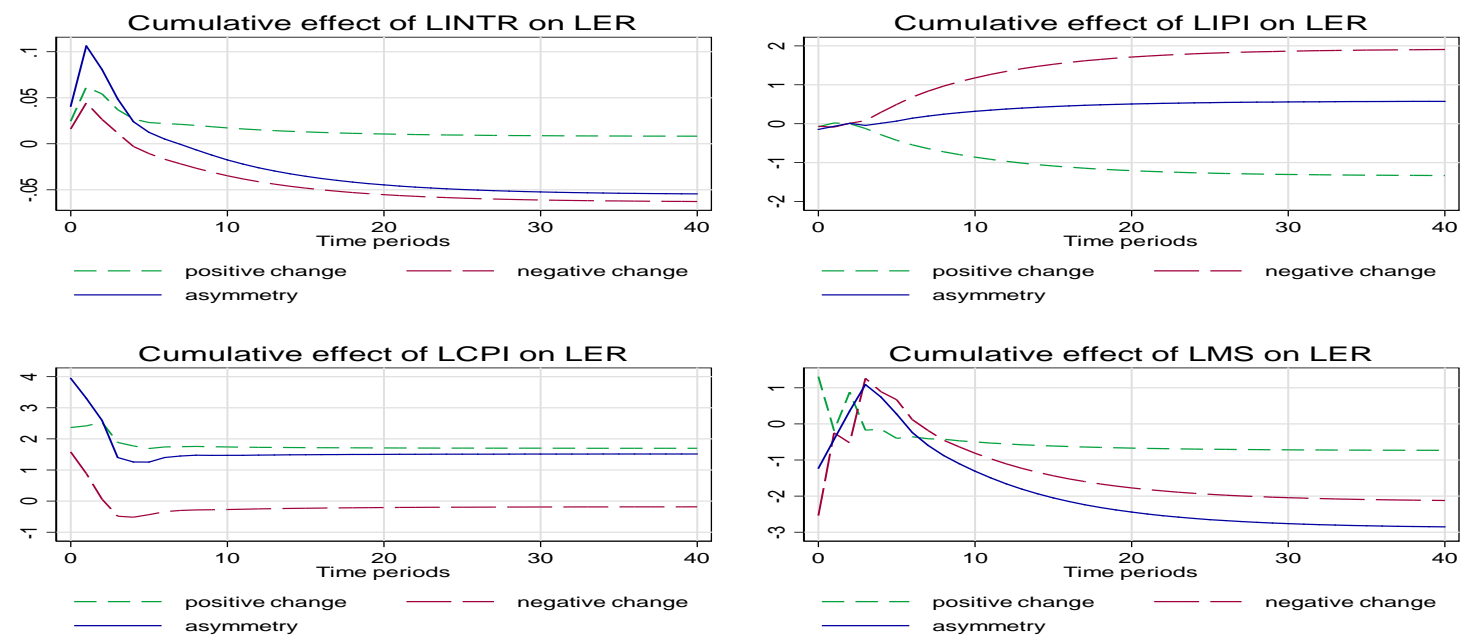

India
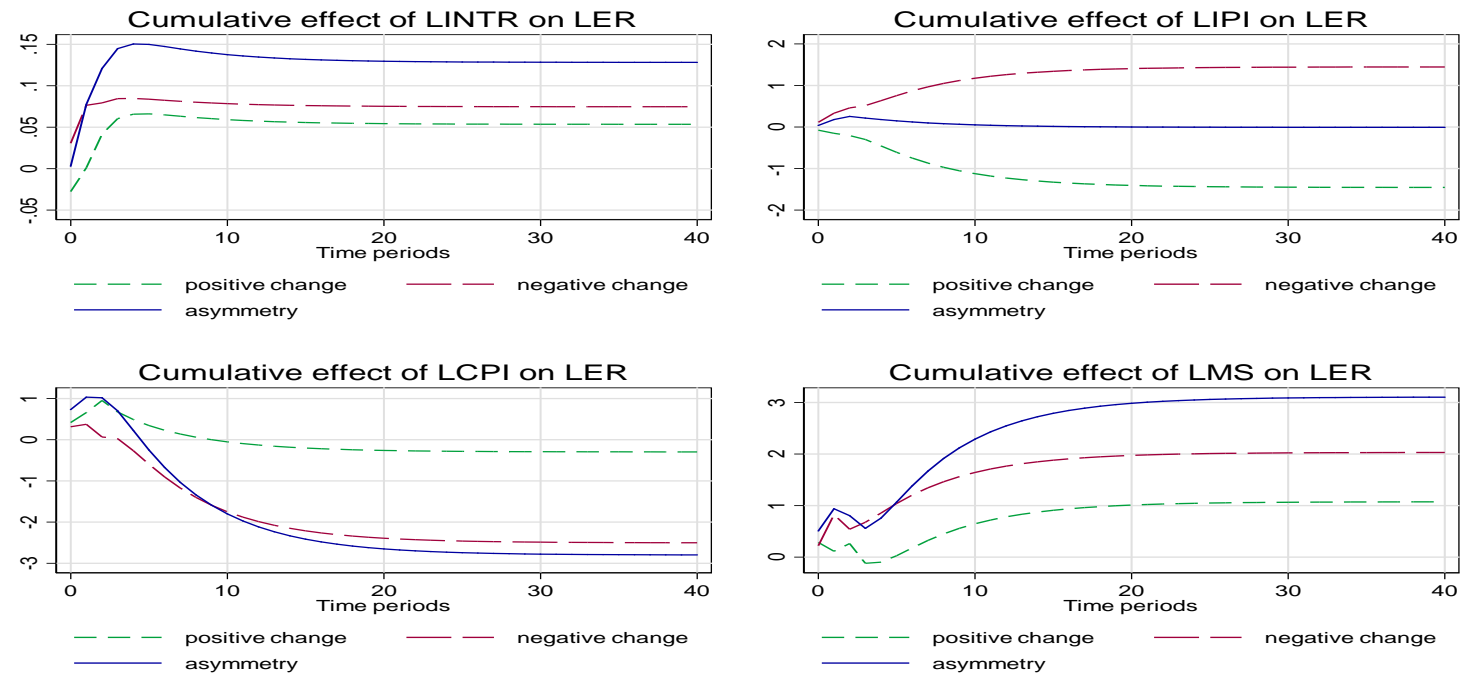


\section{China}
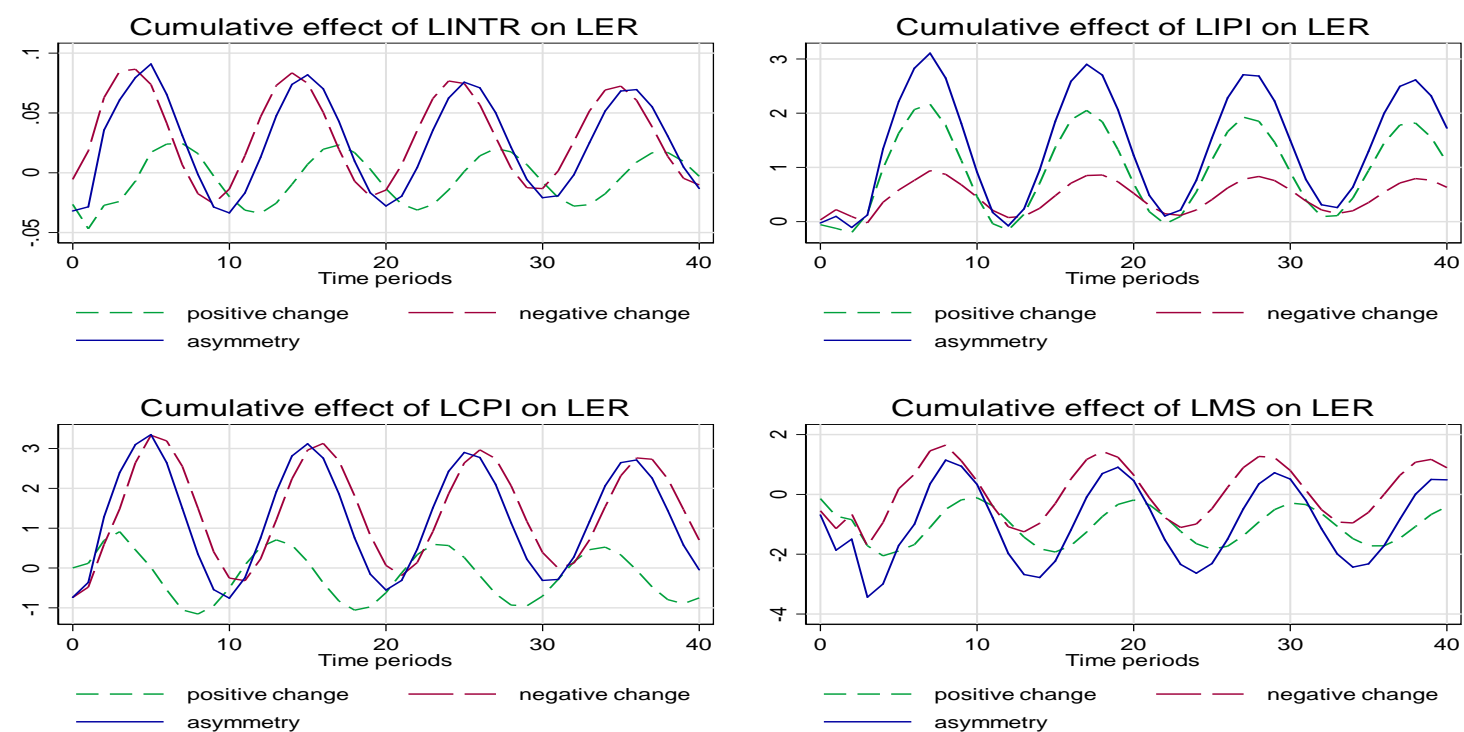

\section{South Africa}
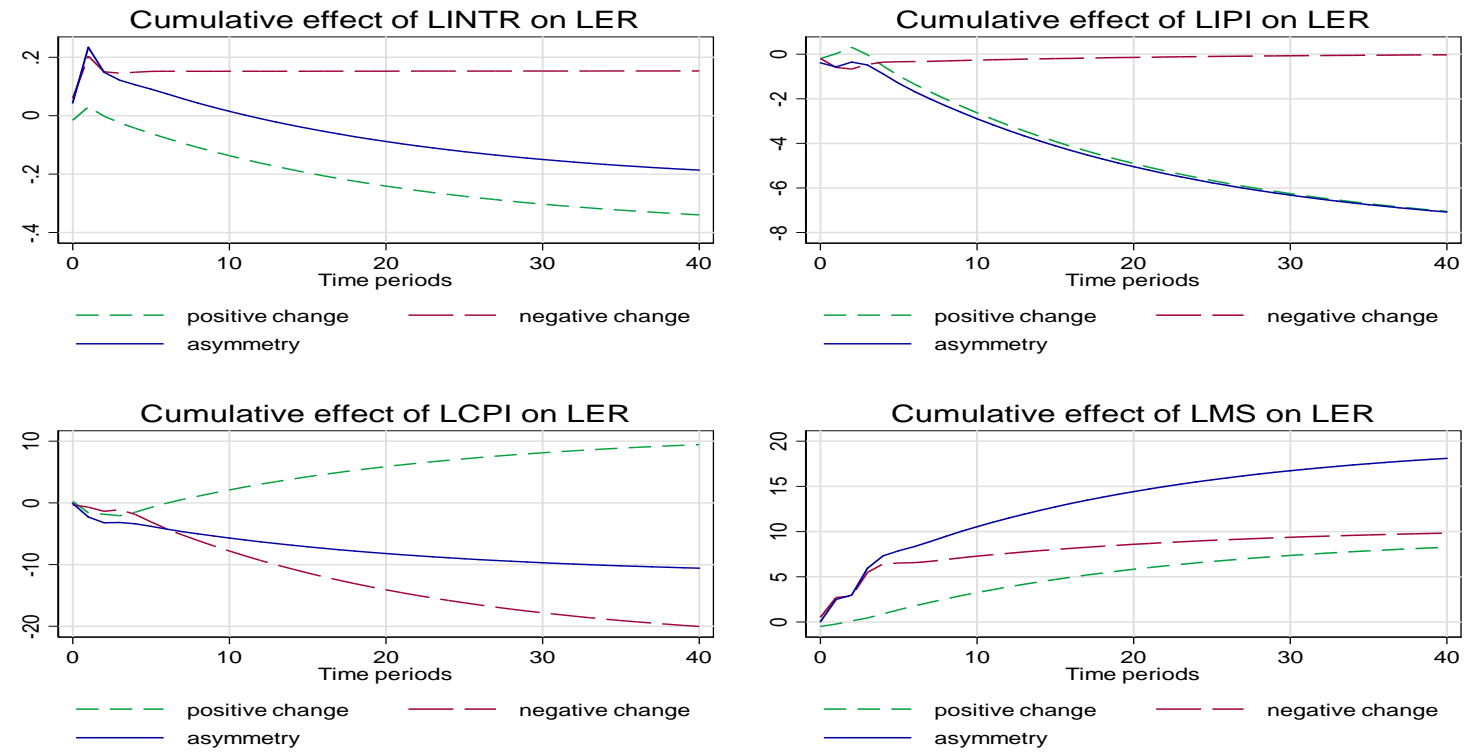

\section{Conclusion}

The study examines the interest rate differential and exchange rate nexus in the BRICS countries, studying the asymmetric relationship and accounting for structural breaks evident in the data. Consequently, we adopt four ARDL variants namely; the linear ARDL model (with and without structural break); and the nonlinear ARDL with and without structural breaks. In the end, the study shows that asymmetry and structural break matter in the largely negative relationships. These are clear in four out of five countries studied. Further results obtained from the graphs of dynamic multipliers clearly show that the nexus between interest rate differential and exchange rate is nonlinear but that of China is of threshold-type, rather than asymmetry-type (i.e. positive and negative asymmetries).

\section{References}

Auten, J. H. (1963) Forward Exchange Rates and Interest-Rate Differentials, Journal of Finance, XVIII, 11-19. 
Beju, D., and Ciupac-Ulici, M. (2015) Taylor Rule in Emerging Countries: Romanian Case, Procedia Economics and Finance, 32, 1122-1130.

Beng, G. W., and Ying, S. L. (2010) Exchange rate and interest rate differential: the case of the Malaysian Ringgit/US Dollar, Applied Economics Letters, 7, 95-97.

Bilson, J. (1978) The monetary approach to the exchange rate - some empirical evidence, International Monetary Fund Papers, 25, 48-75.

Ding, L., and Yang, Q. (2017) Asymmetric impact of monetary surprises on exchange rate, Applied Economics, 50, 789-803.

Dornbusch, R. (1976) Expectations and exchange rate dynamics, Journal of Political Economy, 84, 1161-1176.

Engel, C. (2016) Exchange rates, interest rates, and the risk premium, American Economic Review, 106 (2), 436-474.

Fauzel, S. (2017) The impact of FDI on CO2 emission in a small island developing state: A cointegration approach, Economics and Business Letters, 6(1), 6-13.

Frankel, J. A. (1979) On the Mark: a theory offloating exchange rates based on real interest differentials, American Economic Review, 69(4), 610-622.

Frenkel, J. (1976) A monetary approach to the exchange rate: doctrinal aspects and empirical evidence, Scandinavian Journal of Economics, 78, 255-76.

Galstyan, V., and Velic, A. (2017) Debt thresholds and real exchange rates: An emerging markets perspective, Journal of International Money and Finance, 70, 452-470.

Hacker, R. S., Karlsson, H. K., and Mansson, K. (2014). An investigation of the causal relations between exchange rates and interest rate differentials using wavelets, International Review of Economics and Finance, 29, 321-329.

Hooper, P., and Morton, J. (1982) Fluctuations in the dollar: a model of nominal and real exchange rate determination, Journal of International Money and Finance, 1, 39-56.

Huettner, F., and Sunder, M. (2011) Decomposing R2 with the Owen value, Faculty of Economics and Management Science, University of Leipzig, working paper ref. 100.

Jackman, M., Craigwell, R., and Doyle-Lowe, M. (2013) Nonlinearity in the reaction of the foreign exchange market to interest rate differentials: Evidence from a small open economy with a long-term peg, Applied Financial Economics, 23(4), 287-296

Kilian, L.. and Taylor, M. P. (2003) Why is it so difficult to beat the random walk forecast of exchange rates?, Journal of International Economics, 60, 85-107.

Meese, R., and Rogoff, K. (1983) Empirical exchange rate models of the seventies: do they fit out of sample?, Journal of International Economics, 14, 3-24.

Moosa, I., and Burns, K. (2014) Error correction modelling and dynamic specifications as a conduit to outperforming the random walk in exchange rate forecasting, Applied Economics, 46(25), 3107-3118.

Shin, Y., Yu, B., and Greenwood-Nimo, M. (2014), Modelling asymmetric cointegration and dynamic multipliers in a nonlinear ARDL framework, DOI: 10.2139/ssrn 1807745.

Vygodina, A. V., Zorn, T. S., and DeFusco, R. (2008) Asymmetry in the effects of economic fundamentals on rising and falling exchange rates, International Review of Financial Analysis, 17, 728-746.

Woo, K. Y., and Lee, S. K. (2018) Price convergence in the UK supermarket chains: Evidence from nonlinear cointegration approach, Economics and Business Letters, 7(3), 115-125.

Wulandari, R. (2012) Do credit channel and interest rate channel play important role in monetary transmission mechanism in Indonesia? A structural vector autoregression model, Procedia - Behavioural Sciences, 65, 557-563. 